\title{
Treatment with Peracetic Acid Extends the Vase Life of Lisianthus (Eustoma grandiflorum) Flowers
}

\author{
Fernando de la Riva and Pilar Carolina Mazuela \\ Facultad de Agronomiá, Universidad de Tarapacá, Arica, Chile
}

Juan Eugenio Álvaro and Miguel Urrestarazu'

Departamento de Producción Vegetal, Universidad de Almeriá, La Cañada de San Urbano, E-04120 Almería, Spain

Additional index words. sodium hypochlorite, bud opening, cut flowers, vase solution, sucrose

\begin{abstract}
The effect of peracetic acid on the vase life and bud opening of cut flowers of Lisianthus was investigated. Eustoma grandiflorum is an attractive cut flower with a considerable length of vase life (usually weeks for freshly harvested stems). It is well known that the addition of sucrose into the vase solution increases significantly the longevity of cut flowers. Two different experiments of vase life were carried out. The first used cultivars of the Mariachi Series: Blue, Green, Blue Picotee, and Pink, whereas the second used Rosita White and Piccolo White 1. The control plants (T1) were supplied with tap water. Treatment 2 (T2) was similar to $\mathrm{T} 1$ with the addition of $3 \%$ sucrose. In the third (T3) and fourth (T4) treatments, sodium hypochlorite and a stabilized peracetic mixed system (PAA) were added, respectively. The number of flowers that opened from buds between cultivars was significantly different. With the addition of sucrose into the vase solution, a significant increase in longevity was recorded, which was also observed after the addition of both biocides to the respective treatments. This can be extended up to $15 \%$ by the addition of sucrose to the vase solution and up to $30 \%$ if PAA is incorporated into the vase solution. The results suggest that PAA can be a useful alternative to sodium hypochlorite for vase solutions because it is without the health drawbacks of trihalomethanes. The degradation of PAA is environmentally friendly, because it decomposes to form biodegradable acetic acid and eventually enters the environment as atomic oxygen.
\end{abstract}

Lisianthus is a crop that has acquired importance as a cut flower throughout the world. In Europe, 50 million stems are cultivated as cut flowers; Holland, Spain, Italy, Portugal, and France are the main producing countries (Namesny, 2005).

The use of sucrose as a sugar in holding solutions is a usual practice to extend the vase life of cut flowers (Macnish et al., 2008; Mayak and Dilley, 1976). A requirement for carbohydrates was demonstrated in cut flowers of petunia (Weiss and Haley, 1991), snapdragon (Sang et al., 1991), and Lisianthus (Jamal Uddin et al., 2001).

The postharvest life of cut flowers is often limited by an accumulation of bacteria in hydration solutions and flower stems (Halevy and Mayak, 1981). Various antimicrobial compounds have been described to extend vase life of cut flowers such as chlorine (e.g., sodium hypochlorite), which when used in vase water can reduce the number of bacteria and increase

\footnotetext{
Received for publication 3 Nov. 2008. Accepted for publication 3 Dec. 2008.

This work has been supported by the Spanish Ministry of Education and Science (Project AGL2007-64832/AGR).

We thank Sakata Ornamentals Europe S.L. for the supply of seedlings.

${ }^{1}$ To whom reprint requests should be addressed; e-mail mgavilan@ual.es.
}

flower longevity (Halevy and Mayak, 1981). On the other hand, the efficacy of sodium hypochlorite is relatively poor in acidified (e.g., $\mathrm{pH} 3$ to 4 ) solutions that are typically recommended for hydrating cut flowers (Nowak and Rudnicki, 1990; White, 1999), and it has low efficiency as a disinfectant agent with organic matter. In addition, it can be phytotoxic to flowers (Knee, 2000; van Doorn et al., 1990). The chlorine vapors produce irritation to the skin and respiratory tract. Some trihalomethanes such as chloroform $\left(\mathrm{CHCl}_{3}\right)$ and bromodichloromethane $\left(\mathrm{CHBrCl}_{2}\right)$ may be carcinogenic, mutagenic, teratogenic, or toxic according to numerous studies. In addition, a direct relationship has been found between these substances and the incidences of bladder cancer and congenital anomalies (e.g., Carpenter and Beresford, 1986; Chu et al., 1982; Dunnick and Melnick, 1993; Maxwell et al., 1991; Pilotto, 1995; Ritter et al., 2002; Villanueva et al., 2000). The Environmental Protection Agency (EPA, 1998) has established a limit of $60 \mu \mathrm{g} \cdot \mathrm{L}^{-1}$ for chloroform and $40 \mu \mathrm{g} \cdot \mathrm{L}^{-1}$ for bromoform as a medium risk of contracting cancer. The Council of the European Union's maximum acceptable values for total trihalomethanes is $100 \mu \mathrm{g} \cdot \mathrm{L}^{-1}$ (EECD, 1997). Apart from environmental health problems, chlorination also has a limited effect on reducing micro-organisms on the surface of fruits and vegetables (Sapers, 2001).
Greenspan and Margulies patented peracetic acid in 1950 for treating fruits and vegetables to reduce spoilage from bacteria and fungi (Greenspan and Margulies, 1950). It had been used for purposes ranging from disinfestation of bulbs and nematodes (Hanks and Linfield, 1999) to prevention of other horticultural diseases through disinfecting potting soil and cleaning irrigation equipment (Larose and Abbot, 1998). Although there is a long history of peracetic acid's experimental field use as a fungicide/bactericide, its efficacy has only recently been established. Hei (2000) reported the use to control horticultural diseases in field- or greenhouse-grown plant tissue, seeds, fruits, and growing media and containers. Mixed peracid or peracetic systems are made with peracetic acid (PAA), hydrogen peroxide, and acetic acid. This mix is virtually unaffected by changes in temperature, even in the presence of organic matter (Rodgers et al., 2004). PAA breaks down when it oxidizes organic material and then finally decomposes to carbonic anhydride and water. Spanish regulations allowed the use of hydrogen peroxide and peracetic acid in the drinking and washing water of fruits and vegetables (AENOR, 2005; BOE, 2003). The Environmental Protection Agency (EPA, 1998) authorizes the use of peroxyacetic acid-based additives for fruits and vegetables and washed water (Tsunami ${ }^{\circledR} 100$; Ecolab, Barcelona, Spain). In addition, it is well known that PAA is an oxidant and disinfectant that is more efficient than chlorine or chorine dioxide (Kitis, 2004).

The objective of the present study was to investigate the vase life of different cultivars of Eustoma grandiflorum flowers as influenced by peracetic acid in the holding solution in comparison with hypochlorite sodium. PAAs are presumed to reduce the accumulation of bacteria in water and flower stems while, at the same time, limiting environmental impact as a result of their low toxicity and health safety. In addition, sucrose was also added to the holding solution to extend vase life, which allowed the disinfestation by sodium hypochlorite versus PAA to be evaluated in the presence of organic matter.

\section{Materials and Methods}

Plant material. Lisianthus plants were grown at the University of Almería (Almería, Spain). Seedlings were cultivated in perlite and harvested on 4 Oct. 2006 and 4 June 2007 for Expts. 1 and 2, respectively. The Lisianthus cultivars were: Mariachi Blue, Mariachi Green, Mariachi Blue Picotte, Mariachi Pink, Rosita White, and Piccolo White 1. The selection of these cultivars and crop dates were under commercial consideration from Sakata Ornamental Seeds, Ltd. (Valencia, Spain).

General processing. All vase life experiments were performed in three replicates with 18 stems placed per vase.

Flowering stems were cut with one flower and a second opening, placed in water, and brought, in water, into the laboratory. The flowering stems were at commercial maturity 
and $\approx 70 \mathrm{~cm}$ long. In the laboratory, the stems were recut in air and immediately assigned at random to each treatment depending on the experiment. The container for vase life was filled with $1.5 \mathrm{~L}$ of treatment solution, refilled every $2 \mathrm{~d}$, and completely renewed weekly. Every $2 \mathrm{~d}$, the number of flowers was counted and wilting and/or drooping flowers were removed. Criteria used to determine the end of vase life of each replicate was when the number of flowers per vase was less than six. Maximum flowering was recorded when it had the highest number of open flowers.

The stems were held in an air-conditioned room at $25{ }^{\circ} \mathrm{C}$ and relative humidity $\approx 80 \%$.

Experiments and chemical treatments. Two different experiments were carried out. The first took place with the Mariachi Series: 'Blue', 'Green', 'Blue Picotee' and 'Pink'; the second used 'Rosita White' and 'Piccolo White 1 '. The control plants (T1) were supplied with tap water. Treatment 2 (T2) was identical to T1 plus 3\% sucrose. The third (T3) and fourth (T4) treatments contained the addition of sodium hypochlorite $\left(1 \mathrm{~mL} \cdot \mathrm{L}^{-1}\right.$ with $12.5 \%$ free chlorine concentration; Brenntag Química SA, Sevilla, Spain) and a stabilized peracetic mixed system $\left(0.1 \mathrm{~mL} \cdot \mathrm{L}^{-1}\right.$ from VR2828 ${ }^{\circledR}$; Ecolab) with a.i. 5\% peracetic acid and $24 \%$ hydrogen peroxide, respectively.

Experimental design and data analysis. All experiments were carried out under a randomized complete block design within a controlled environmental room according to Little and Hills (1987) and Petersen (1994).

The least significant difference test was used to separate means within experiments and STATGRAPHICS Plus Version 5.1 statistical package was used to process data (Statistical Graphics Corp., 2006).

\section{Results and Discussion}

Among cultivars of Expt. 1, the number of buds that opened flowers was significantly different $(P<0.01)$; in contrast, no significant differences were found for cultivars in Expt. 2 (Table 1). In Expt. 1, the Mariachi Blue cultivar was the Lisianthus that had more flowers per stem. In Expt. 1 (considering all treatments), the order of cultivars from more to less flowers per stem was: 'Mariachi Blue' = 'Mariachi Green' $\geq$ 'Mariachi Blue Picotee' = 'Mariachi Pink'.

Except for 'Mariachi Blue' and 'Mariachi Green' (in Expt. 1), the remaining cultivars showed a significant difference in number of flowers per stem when sucrose was supplied in the vase solution $(P<0.01)$. Sucrose increased the number of flowers from $30 \%$ for 'Mariachi Blue Picotee' and up to $\approx 40 \%$ for 'Mariachi Pink'. These results agree with the reported difference in cut flowers (Sang et al., 1991; Weiss and Haley, 1991), and Lisianthus (Jamal Uddin et al., 2001).

The addition of disinfectant agent, sodium hypochlorite, and PAA in the vase solution did not improve the number of open flowers.

The time needed for the stem to show maximum flowering was only slightly affected by the different treatments (Table 2). In only two of five cases was a significant difference found. 'Piccolo White 1', in Expt. 2, required more time $(\approx 4 \mathrm{~d}, P<0.01)$ to reach the phase of maximum flowering when sucrose was supplied in the vase solution. On other hand, cultivars treated with sodium hypochlorite and sucrose (in Expt. 1) needed more time $(\approx 2$ to $3 \mathrm{~d}$ ) to get to this same phase than when PAA was used. Considering the control stems (T1), there were significant differences among

different Lisianthus cultivars ( $\approx 50 \%$, Expt. 2 ; and $25 \%$, Expt. 1). So, the time necessary for flower opening was related to the cultivar more than to the different treatments.

Placement of flowers, in Expts. 1 and 2, into vase water containing 3\% sucrose extended vase life by $12 \%$ and $50 \%$, respectively (Table 3). This was in accordance with reports by different authors (Jamal Uddin et al., 2001; Sang et al., 1991; Weiss and Haley, 1991).

Table 1. Number of open flowers per stem from buds throughout vase life for Lisianthus cut flowers in different treatments of vase solution.

\begin{tabular}{|c|c|c|c|c|c|c|}
\hline Cultivar & $\mathrm{T} 1$ & $\mathrm{~T} 2$ & $\mathrm{~T} 3$ & $\mathrm{~T} 4$ & $\operatorname{LSD}_{0.05}$ & $\operatorname{LSD}_{0.01}$ \\
\hline \multicolumn{7}{|l|}{ Expt. 1} \\
\hline Mariachi Blue & 7.03 & 6.64 & 7.03 & 6.97 & NS & NS \\
\hline Mariachi Green & 6.95 & 6.89 & 7.72 & 7.28 & NS & NS \\
\hline $\begin{array}{l}\text { Mariachi Blue } \\
\text { Picotee }\end{array}$ & 3.69 & 4.97 & 5.22 & 5.78 & 0.88 & 1.20 \\
\hline Mariachi Pink & 3.72 & 6.06 & 6.33 & 6.86 & 1.04 & 1.42 \\
\hline $\mathrm{LSD}_{0.05}$ & 0.74 & 1.16 & 1.05 & 1.18 & & \\
\hline $\operatorname{LSD}_{0.01}$ & 1.01 & 1.58 & 1.43 & NS & & \\
\hline \multicolumn{7}{|l|}{ Expt. 2} \\
\hline Rosita White & 6.00 & 9.03 & 9.19 & 9.30 & 1.75 & 2.39 \\
\hline Piccolo White 1 & 5.81 & 9.03 & 10.03 & 9.78 & 1.85 & 2.52 \\
\hline $\operatorname{LSD}_{0.05}$ & NS & NS & NS & NS & & \\
\hline $\operatorname{LSD}_{0.01}$ & NS & NS & NS & NS & & \\
\hline
\end{tabular}

Values are the mean of three blocks with 18 stems per replicate.

$\mathrm{T} 1=$ tap water; $\mathrm{T} 2=$ tap water $+3 \%$ sucrose $; \mathrm{T} 3=$ tap water $+3 \%$ sucrose $+1 \mathrm{~mL} \cdot \mathrm{L}^{-1}$ sodium hypochlorite; $\mathrm{T} 4=$ tap water $+3 \%$ sucrose $+0.1 \mathrm{~mL} \cdot \mathrm{L}^{-1}$ peracetic mixed system; $\mathrm{LSD}=$ least significant difference; $\mathrm{NS}=$ nonsignificant.

Table 2. Days until maximum flowering for Lisianthus cut flowers in different treatments of vase solution.

\begin{tabular}{|c|c|c|c|c|c|c|}
\hline Cultivar & $\mathrm{T} 1$ & $\mathrm{~T} 2$ & T3 & $\mathrm{T} 4$ & $\operatorname{LSD}_{0.05}$ & $\operatorname{LSD}_{0.01}$ \\
\hline \multicolumn{7}{|l|}{ Expt. 1} \\
\hline Mariachi Blue & 6.02 & 8.50 & 6.67 & 7.50 & NS & NS \\
\hline Mariachi Green & 7.00 & 6.33 & 7.17 & 8.33 & NS & NS \\
\hline $\begin{array}{l}\text { Mariachi Blue } \\
\text { Picotee }\end{array}$ & 6.00 & 6.00 & 9.00 & 6.67 & 2.74 & NS \\
\hline Mariachi Pink & 8.00 & 8.33 & 7.33 & 6.67 & NS & NS \\
\hline $\operatorname{LSD}_{0.05}$ & 1.92 & NS & NS & NS & & \\
\hline $\operatorname{LSD}_{0.01}$ & NS & NS & NS & NS & & \\
\hline \multicolumn{7}{|l|}{ Expt. 2} \\
\hline Rosita White & 11.17 & 12.00 & 13.00 & 11.17 & NS & NS \\
\hline Piccolo White 1 & 6.00 & 10.33 & 9.17 & 11.83 & 2.67 & 3.65 \\
\hline $\operatorname{LSD}_{0.05}$ & 1.06 & NS & NS & 0.52 & & \\
\hline $\operatorname{LSD}_{0.01}$ & 1.51 & NS & NS & NS & & \\
\hline
\end{tabular}

Values are the mean of three blocks with 18 stems per replicate.

$\mathrm{T} 1=$ tap water; $\mathrm{T} 2=$ tap water $+3 \%$ sucrose $; \mathrm{T} 3=$ tap water $+3 \%$ sucrose $+1 \mathrm{~mL} \cdot \mathrm{L}^{-1}$ sodium hypochlorite; $\mathrm{T} 4=$ tap water $+3 \%$ sucrose $+0.1 \mathrm{~mL} \cdot \mathrm{L}^{-1}$ peracetic mixed system; $\mathrm{LSD}=$ least significant difference; $\mathrm{NS}=$ nonsignificant.

Table 3. Longevity of vase life (days) for Lisianthus cut flowers in different treatments of vase solution.

\begin{tabular}{lcccccc}
\hline Cultivar & $\mathrm{T} 1$ & $\mathrm{~T} 2$ & $\mathrm{~T} 3$ & $\mathrm{~T} 4$ & LSD $_{0.05}$ & LSD $_{0.01}$ \\
\hline Expt. 1 & 14.67 & 17.02 & 19.00 & 19.00 & 1.34 & 1.81 \\
Mariachi Blue & 13.50 & 16.33 & 18.00 & 17.17 & 1.90 & 2.59 \\
Mariachi Green & 12.67 & 16.00 & 16.33 & 17.00 & 1.67 & 2.59 \\
Mariachi Blue & & & & & \\
$\quad$ Picotee & 13.67 & 16.33 & 16.67 & 17.67 & 1.60 & 2.18 \\
Mariachi Pink & 2.01 & $\mathrm{NS}$ & 1.72 & 1.83 & & \\
$\quad$ LSD 0.05 & $\mathrm{NS}$ & $\mathrm{NS}$ & 2.34 & $\mathrm{NS}$ & & \\
$\quad$ LSD $_{0.01}$ & & & & & \\
Expt. 2 & 12.00 & 25.33 & 26.00 & 26.00 & 1.81 & 2.47 \\
Rosita White & 12.17 & 17.50 & 21.00 & 20.00 & 2.32 & \\
Piccolo White 1 & $\mathrm{NS}$ & 2.78 & 1.96 & 1.73 & & \\
$\quad$ LSD $_{0.05}$ & $\mathrm{NS}$ & 3.96 & 2.76 & 2.46 & & \\
$\quad$ LSD $_{0.01}$ & & & & & \\
\hline
\end{tabular}

Values are the mean of three blocks with 18 stems per replicate.

$\mathrm{T} 1=$ tap water; $\mathrm{T} 2=\operatorname{tap}$ water $+3 \%$ sucrose $; \mathrm{T} 3=\operatorname{tap}$ water $+3 \%$ sucrose $+1 \mathrm{~mL} \cdot \mathrm{L}^{-1}$ sodium hypochlorite; $\mathrm{T} 4=$ tap water $+3 \%$ sucrose $+0.1 \mathrm{~mL} \cdot \mathrm{L}^{-1}$ peracetic mixed system; $\mathrm{LSD}=$ least significant difference; $\mathrm{NS}=$ nonsignificant. 
Except for 'Rosita White' in Expt. 2, all treatments with vase water disinfestations increased vase life $(P<0.01)$. Different grades of effects were found in each cultivar. 'Mariachi Blue' and 'Piccolo White 1' showed the longest longevity after treatment with disinfestation solutions (T3 and T4) than when only sucrose (T2) was used. The extension of cut flower vase life longevity by biocidal compounds has previously been described (e.g., sodium hypochlorite, Halevy and Mayak, 1981; chlorine dioxide, Macnish et al., 2008). There were no significant differences when T3 and T4 were compared. However, stabilized hydrogen peroxide and PAA mixtures are more environmentally friendly, and, consequently, the use of PAA is more suitable than sodium hypochlorite. A similar idea has been reported by Eguía et al. (2007), who compared sodium hypochlorite as a biocide, but in a different context (used on biofilms in pipes).

\section{Conclusion}

Lisianthus is an attractive cut flower with a considerable length of vase life $(\approx 2$ weeks). This can be extended by $15 \%$ to $50 \%$ with the addition of sucrose $(3 \%)$ to the vase solution and up to $30 \%$ to $55 \%$ if stabilized hydrogen peroxide and peroxyacetic acid is also incorporated.

PAA can be a useful alternative to sodium hypochlorite for vase solutions because it is without the health drawbacks of trihalomethanes. After its use, the emission of PAA is environmentally friendly, because it forms biodegradable acetic acid after decomposition and eventually enters the medium as atomic oxygen.

\section{Literature Cited}

AENOR. 2005. Asociación Española de Normalización y Certificación. UNE 155000. Frutas y hortalizas frescas.

BOE. 2003. RD/140/2003. $\mathrm{n}^{\circ}$ 45. Boletín Oficial del Estado. Spain. p. 7228-7245.

Carpenter, L.M. and S.A. Beresford. 1986. Cancer mortality and type of water source: Findings from a study in the UK. Intl. J. Epidemiol. $15: 312-320$

Chu, I., D.C. Villeneuve, V.E. Secours, G.C. Becking, and V.E. Valli. 1982. Toxicity of trihalomethanes: The acute and subacute tox- icity of chloroform, bromodichloromethne, chlorodibromomethene and bromoform in rats. Journal of Environmental Science and Health 17:205-224.

Dunnick, J.K. and R.L. Melnick. 1993. Assessment of the carcinogenic potential of chlorinated water: Experimental studies of chlorine, chloramines and trihalomethanes. J. Natl. Cancer Inst. 85:817-822.

EECD. 1997. European Economic Community Directive. Amended proposal for a Council Directive concerning the quality of water intended for human consumption-Common position. In: Proc. of the Council of the European Union, Directive 80/778/EEC, Com (97) 228 Final 95/ 0010 SYN, Brussels, Belgium.

Eguía, E., A. Trueba, A. Girón, B. Río-Caonge, F. Otero, and C. Bielva. 2007. Optimisation of biocide dose as a function of residual biocide in a heat exchanger pilot plant effluent. Biofouling 23:231-247.

EPA. 1998. Food and Drug Administration. Pub. No. 98-18287 21 CFR Part 101. U.S. Health and Human Services. Springfield, VA.

Greenspan, F.P. and P.H. Margulies. 1950. Treatment of raw plant tissue. US Patent 2512640. Buffalo Electro-chemical Co.

Halevy, A.H., and S. Mayak. 1981. Senescence and postharvest physiology of cut flowers. Part 2. Hort. Rev. 3:59-153.

Hanks, G.R. and C.A. Linfield. 1999. Evaluation of a peroxyacetic acid disinfectant in hot-water treatment for the control of basal rot (Fusarium oxysporum f. sp. narcissi) and stem nematode (Ditylenchus dipsaci) in narcissus. J. Phytopathol. 147:271-279.

Hei, R.D.P. 2000. Peroxy acid treatment to control pathogenic organisms on growing plants. US Patent 6024986.

Jamal Uddin, A.F.M., F. Hashimoto, M. Kaketani, K. Shimizu, and Y. Sakata. 2001. Analysis of light and sucrose potencies on petal coloration and pigmentation of Lisianthus cultivars (in vitro). Sci. Hort. 89:75-84.

Kitis, M. 2004. Disinfection of wastewater with peracetic acid: A review. Environ. Intl. 30:47-55.

Knee, M. 2000. Selection of biocides for use in floral preservatives. Postharvest Biol. Technol. 18:227-234.

Larose, R.N. and M.N. Abbot. 1998. Method for control of horticulture diseases, and decontamination of plant tissue. US Patent 5723406.

Little, T.M. and F.J. Hills. 1987. Métodos estadísticos para la investigación en la agricultura. Ed. Trillas, México.

Macnish, A.J., R.T. Leonard, and T.A. Nel. 2008. Treatment with chlorine dioxide extends the vase life of selected cut flowers. Postharvest Biol. Technol. 50:197-207.
Maxwell, N.I., D.E. Burmaster, and D. Ozonoff. 1991. Trihalomethanes and maximum contaminant levels: The significance of inhalation and dermal exposures to chloroform in household water. Regul. Toxicol. Pharmacol. 14:297-312.

Mayak, S. and D. Dilley. 1976. Effect of sucrose on response of cut carnation flowers to kinetin, ethylene and abscisic acid. J. Amer. Soc. Hort. Sci. 101:583-585.

Namesny, A. 2005. De lisianthus a capsicum mejora genética en ornamentales. Horticultura 47:34-37.

Nowak, J. and R.M. Rudnicki. 1990. Postharvest handling and storage of cut flowers, florist greens, and potted plants. Chapman and Hall, London, UK.

Petersen, R.G. 1994. Agricultural field experiments. Marcel Dekker Inc., New York, NY.

Pilotto, L.S. 1995. Disinfection of drinking water, disinfection by-products and cancer: What about Australia. Aust. J. Public Health 19:89-93.

Ritter, L., K. Solomon, P. Sibley, K. Hall, P. Keen, G. Mattu, and B. Linton. 2002. Sources, pathways, and relative risks of contaminant in surface water and groundwater: A perspective prepared for the Walkerton inquiry. J. Toxicol. Environ. Health 65:1-142.

Rodgers, S.T., J.N. Cash, M. Siddiq, and E.T. Ryser. 2004. A comparison of different chemical sanitizers for inactivating Escherichia coli O157:H7 and Listeria monocytogenes in solution and on apples, lettuce, strawberries and cantaloupe. J. Food Prot. 67:721-731.

Sang, C.K., Y.S. Choi, and H.Y. Kim. 1991. Effects of light intensity, sucrose and growth regulators on the coloration of cut snapdragon flower. J. Kor. Soc. Hort. Sci. 35:10111018 .

Sapers, G.M. 2001. Efficacy of washing and sanitizing methods for disinfection of fresh fruits and vegetable products. Food Technol. Biotechnol. 39:305-311.

Statistical Graphics Corp. 2006. STATGRAPHICS Plus for Windows 4.1. Statistical Graphics Corp., Rockville, MD.

Van Doorn, W.G., Y. De Witte, and R.R.J. Perik. 1990. Effect of antimicrobial compounds on the number of bacteria in stems of cut rose flowers. J. Appl. Bacteriol. 68:117-122.

Villanueva, C.M., M. Kogevinas, and J.O. Grimalt. 2000. Cloración del agua potable en España y cáncer de vejiga. Gac. Sanit. 15:48-53.

White, G.C. 1999. Handbook of chlorination and alternative disinfectants. 4th Ed. John Wiley \& Sons, New York, NY.

Weiss, D. and A.A. Haley. 1991. The role of light reactions in the regulation of anthocyanin synthesis in petunia corollas. Physiol. Plant. 81:127-133. 